with crush injuries of the chest it cannot be assumed that oxygenation is adequate on the basis of the finding of a normal $\mathrm{P}_{\mathrm{a}} \mathrm{CO}_{2}$. (2) In these patients the inspired gases should be enriched with oxygen no matter what the mode or amount of ventilation. Even then hypoxaemia may still be present. Further therapy should aim at promoting expansion of the lungs and at restoring to normal the circulating blood volume and the oxygen-carrying capacity of the blood.

\section{Summary}

Arterial blood-gas analyses have been performed on nine patients who had sustained chest injuries. After tracheostomy and in the absence of pulmonary tamponade the lungs were capable of maintaining normal or subnormal carbon dioxide tensions, but in all cases there was a reduction in the percentage saturation with oxygen of the arterial blood, and in some patients this was not corrected fully with oxygen therapy. Some of the implications of these findings are discussed.
We wish to thank Professor J. C. Goligher, the late Mr. M. C. Oldfield, Mr. A. B. Pain, Dr. F. M. Parsons, Mr. H. S. Shucksmith, Mr. F. G. Smiddy, and Mr. D. A. Watson, under whose care these patients were admitted, for permission to publish; Dr. J. J. L. Ablett and Dr. D. W. Clark, who supervised their respiratory management ; Mr. G. H. Wooler, Director of the Thoracic Surgical Department, in whose laboratories the blood-gas analyses were performed; and Dr. V. A. Grimshaw for advice in the preparation of this paper.

\section{REFERENCES}

Andersen, O. S., Engel, K., Jørgensen, K., and Astrup, P. (1960). Scand. f. clin. Lab. Invest., 12, 172.

Astrup, P. (1959). In Symposium on pH and Blood Gas Measuremens. edited by $\mathrm{R}$. F. Woolmer. Churchill, London.

Avery, E. E., Mörch, E. T., and Benson, D. W. (1956). 7. thorac. Surg.. 32, 291 .

Barrett, N. R. (1960). Lancet, 1, 293.

Campbell, E. J M and Howell, J. B. L. (1960). Brit. med. 7., 1, 458.

Gelin, L. E. (1961). Acta chir. scand., 122, 287.

Griffiths, H. W. C. (1960). 7. roy. Coll. Surg. Edinb., 6, 13.

Harley, H. R. S. (1961). Proc. roy. Soc. Med., 54, 558 .

Maloney, J. V., Schmutzer, K. J., and Raschke, E. (1961). 7. thorac. cardiovasc. Surg., 41, 291.

Sellors, T. H. (1961). Thorax, 16, 1.

\title{
Steroids in Treatment of the Nephrotic Syndrome in Adults*
}

\author{
H. GOTZE, $†$ M.D. ; W. T. E. MCCAUGHEY, $\ddagger$ M.D. ; R. A. WOMERSLEY,§ M.D., M.R.C.P.
}

Brit. med. F., 1964, 1, 351-354

The nephrotic syndrome in adults, as characterized by proteinuria, hypoproteinaemia, and oedema, has a multiple aetiology. Some of the diseases with which it may be associated are relatively easily defined, but there remain a large number of cases in which the renal lesion is not usually certain. Where specific therapy for a causative condition has not been available, treatment has generally been directed towards relieving the most prominent symptom, the oedema, either by the infusion of plasma-volume expanders, such as concentrated human serum albumin, or by promoting the loss of salt and water from the body by the use of diuretics, low-salt diets, and exchange resins. While these measures have often been successful in their objective, they have not been thought to influence the renal defect responsible for the heavy proteinuria, which is the primary cause of the oedema. A further difficulty in assessing the response of this condition to any form of treatment is the recognized fact that some cases will recover, with loss of proteinuria, either spontaneously or after any measure to reduce oedema.

The nephrotic syndrome in children has always had a better prognosis than that in adults, but with the introduction of adrenocorticotrophic hormone and cortisone therapy it became obvious that the remission rate was dramatically improved (Lange et al., 1957 ; Charlton et al., 1958 ; Arneil, 1961). Experience with this form of treatment in the adult is not only more limited but there is much less certainty of its effectiveness (Blainey et al., 1960 ; Burch et al., 1962 ; Sharpe and Unger, 1959).

We report here 26 cases of the nephrotic syndrome in adults treated with prolonged steroid therapy.

\section{Material and Methods}

A total of 26 patients have been treated, of whom 14 were males and 12 females, with ages from 15 to 58 years. All those selected for treatment had a proteinuria of above 3 g. In 24 hours, and hypoproteinaemia. Oedema had been present at some time in the course of the disease in all subjects, but wa not necessarily so when treatment was started. An elevated blood-pressure or blood urea was not regarded as a bar to treatment. In most cases the concentration of cholesterol in the serum was above normal. Only cases in which the nephrotic syndrome was diagnosed, either on renal biopsy or on clinical grounds, as being of unknown aetiology were included in the trial. The large number of unrelated diseases in which the nephrotic syndrome may occur as a complication were specifically excluded.

The patients were admitted to hospital for initial study and the commencement of steroid therapy. In the preliminary work and in the follow-up clinic, observations were made on the 24-hour excretion of protein in the urine, the plasma proteins, the blood urea, the clearance of endogenous creatinine, and the serum cholesterol. On discharge from hospital followup appointments were made at monthly intervals so far as practicable. The steroid used was prednisolone in all cases except one, when methylprednisolone was used. Two cases were started on methylprednisolone, but later were switched to prednisolone. The initial dose of prednisolone varied between 20 and $80 \mathrm{mg}$./day; thereafter the dose was in most cases altered according to the response obtained as judged by the degree of proteinuria. Where the level of protein excretion did not diminish, the dose of steroid was lowered in order to reduce toxic side-effects. The maintenance dose of prednisolone varied between 10 and $20 \mathrm{mg}$./day. All patients were on a high-protein diet, and if oedema was present salt restriction and diuretic therapy were used. Continuous prophylactic

^From the Department of Medicine and Pathology, the Queen's University of Belfast.

† British Council Scholar. ‡ Lecturer, Department of Pathology. S Senior Lecturer, Department of Medicine. 
antibiotics were not given. Thirteen cases were studied by percutaneous renal biopsy.

Urine protein was estimated by precipitation with trichloroacetic acid and determination of protein nitrogen by the Biuret reaction. Serum and urine creatinine were estimated by a method modified from Peters (1942). Other chemical determinations were made by standard laboratory methods.

\section{Results}

The 13 cases studied by renal biopsy were divided into three groups according to the histological findings in the biopsy specimen. In group 1 the glomeruli showed minimal changes. Group 2 cases were classified as showing membranous glomerulonephritis. In these the principal glomerular abnormality was a diffuse and usually mild thickening of the capillary walls. The thickened walls were sharply defined, and the capillary lumina which they bounded often appeared rather more rounded than those in normal glomeruli. Mild swelling of the epithelial cells was commonly present, as were occasional small focal proliferations of endothelial nuclei. Group 3 cases were classified as showing a mixed proliferative and membranous lesion. Here the glomeruli showed a diffuse mild or moderate excess of endothelial-type nuclei, and the capillary walls were less clearly defined than in the membranous group. In some

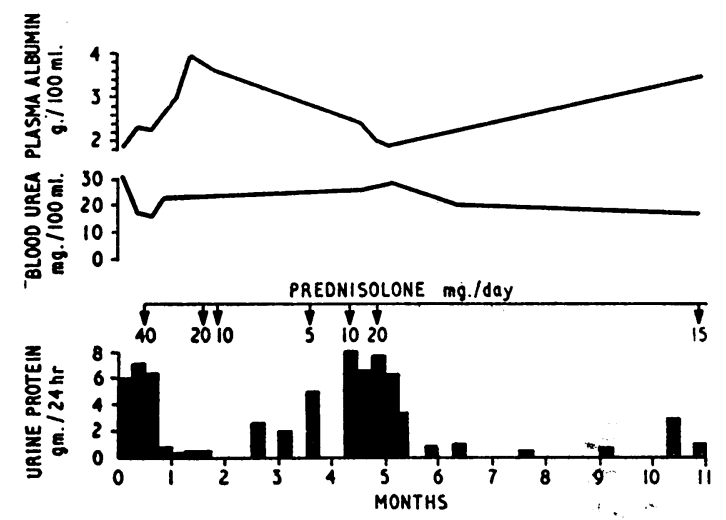

FIG. 1.-Response to prednisolone in Case 1.

capillary walls, however, thickening identical to that in the membranous cases was seen. On these criteria one case was placed in group 1, eight were in group 2 , and four were in group 3. The data for these cases are shown in Table I.

Group 1 (Case 1).-There was only one case in this group. The patient was a 15-year-old boy who had massive oedema when steroid therapy was started. His proteinuria rapidly diminished, and this was associated with a rise in his plasmaalbumin concentrations (Fig. 1). When the prednisolone was reduced from the initial dose of $40 \mathrm{mg}$./day to $5 \mathrm{mg}$./day his proteinuria returned to pretreatment levels and oedema developed. The dose of prednisolone was increased to 20 $\mathrm{mg}$./day, when his proteinuria again diminished and clinical improvement followed. It seems reasonable to postulate that in this boy's case there is evidence that the level of protein excretion was controlled by the steroid therapy, since there were no other factors, other than a reduction in steroid dosage, to which the relapse at the fourth month could be attributed.

Group 2 (Cases 2-9).- There were eight patients in this group. In two (Cases 4 and 6) the urine became protein-free during treatment, and in one (Case 9) the protein output fell to less than $1 \mathrm{~g}$. in 24 hours. None of the remaining cases showed substantial improvement. In Case 4 the patient, a

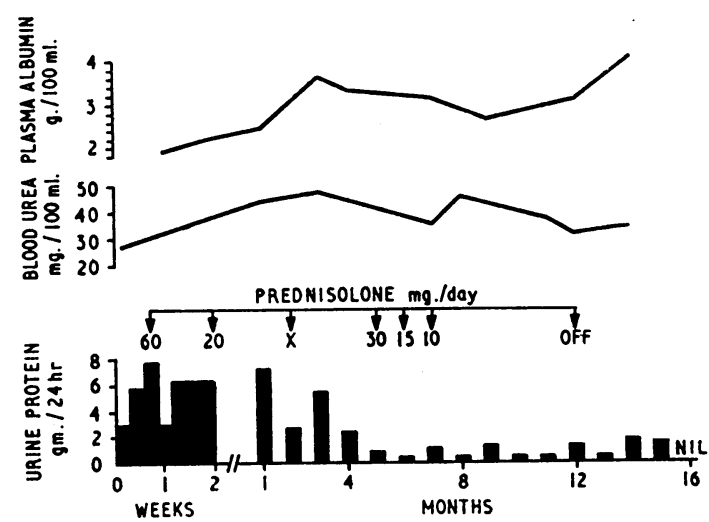

FIG. 2.-Response to prednisolone in Case 4. From $\mathrm{X}$ to the twelfth month, steroid was given on only three consecutive days in the week.

45-year-old woman, had had oedema of the legs, hands, and face for eight months. She had had a two-weeks course of dexamethasone, without clinical improvement, six months before entry to the trial. On steroid therapy her proteinuria diminished over a period of four months, with a rise in the plasma-albumin concentration and disappearance of oedema (Fig. 2). After 13 months' treatment it was considered that she had an irreducible minimal proteinuria and steroid was stopped. Four months later the urine became free of protein and has remained so over a follow-up period of 12 months. The more usual course in this group is shown by Case 3 (Fig 3). A 23-year-old man presented with a month's history of oedema of the face and ankles, following a sore throat. His initial proteinuria was $11.7 \mathrm{~g} . / 24$ hours and his plasma albumin 1.4 g. $/ 100 \mathrm{ml}$. During treatment with prednisolone for 12

TABLE I

\begin{tabular}{|c|c|c|c|c|c|c|c|c|c|c|c|c|c|c|c|}
\hline \multirow{2}{*}{$\begin{array}{l}\text { Case } \\
\text { No. }\end{array}$} & \multirow{2}{*}{ Age } & \multirow{2}{*}{ Sex } & \multirow{2}{*}{$\begin{array}{c}\text { Duration } \\
\text { oN } \\
\text { Treatment } \\
\text { (Months) }\end{array}$} & \multicolumn{2}{|c|}{$\begin{array}{l}\text { Urine Protein } \\
(\text { g. } / 24 \mathrm{hr} .)\end{array}$} & \multicolumn{2}{|c|}{$\begin{array}{l}\text { Plasma Albumin } \\
\text { (g./100 ml.) }\end{array}$} & \multicolumn{2}{|c|}{$\begin{array}{l}\text { Blood Urea } \\
\text { (mg./100 ml.) }\end{array}$} & \multicolumn{2}{|c|}{$\begin{array}{c}\text { Creatinine Clearance } \\
\text { (ml./min.) }\end{array}$} & \multicolumn{2}{|c|}{$\begin{array}{l}\text { Serum Cholesterol } \\
\text { (mg. } / 100 \mathrm{ml} .)\end{array}$} & \multirow{2}{*}{$\begin{array}{c}\text { Duration } \\
\text { OFF } \\
\text { Treatment } \\
\text { (Months) }\end{array}$} & \multirow{2}{*}{$\mid \begin{array}{c}\begin{array}{c}\text { Urine } \\
\text { Protein } \\
\text { (mg.!100 ml. }\end{array} \\
\text { P }\end{array}$} \\
\hline & & & & C & $T$ & C & $\mathrm{T}$ & C & $T$ & C & $\mathrm{T}$ & C & $\mathbf{T}$ & & \\
\hline \multicolumn{16}{|c|}{ Group 1} \\
\hline 1 & 15 & $M$ & 10 & $6 \cdot 4$ & 0.6 & $2 \cdot 2$ & 3.5 & 16 & 18 & - & - & 580 & 228 & - & - \\
\hline $\begin{array}{l}2 \\
3 \\
4 \\
5 \\
6 \\
7 \\
8 \\
9\end{array}$ & $\begin{array}{l}22 \\
23 \\
45 \\
32 \\
36 \\
55 \\
46 \\
52\end{array}$ & $\begin{array}{c}\mathbf{M}^{*} \\
\mathbf{M} \\
\mathbf{M} \\
\mathbf{M} \\
\mathbf{F} \\
\mathbf{M} \\
\mathbf{M}\end{array}$ & $\begin{array}{r}16 \\
12 \\
13 \\
33 \\
10 \\
11 \\
28 \\
9\end{array}$ & $\begin{array}{r}10.9 \\
11.7 \\
6.1 \\
5.9 \\
6.7 \\
7.4 \\
7.7 \\
12.1\end{array}$ & $\begin{array}{c}8.2 \\
16.9 \\
0 \\
5.6 \\
0 \\
2.1 \\
1.8 \\
0.4\end{array}$ & $\begin{array}{l}2.6 \\
1.5 \\
1.9 \\
1.8 \\
2.5 \\
3.0 \\
2.2 \\
1.5\end{array}$ & $\begin{array}{l}2.5 \\
1.5 \\
4.0 \\
3.1 \\
3.7 \\
2.9 \\
3.0\end{array}$ & $\begin{array}{c}\text { roup } \\
29 \\
25 \\
27 \\
28 \\
41 \\
46 \\
54 \\
39\end{array}$ & $\begin{array}{l}28 \\
44 \\
34 \\
52 \\
34 \\
52 \\
38 \\
30\end{array}$ & $\begin{array}{r}117 \\
75 \\
90 \\
116 \\
110 \\
116 \\
121 \\
123\end{array}$ & $\begin{array}{r}149 \\
138 \\
111 \\
128 \\
72 \\
112 \\
92\end{array}$ & $\begin{array}{l}324 \\
459 \\
236 \\
414 \\
310 \\
463 \\
304\end{array}$ & $\begin{array}{l}392 \\
394 \\
270 \\
318 \\
274 \\
395 \\
235 \\
256\end{array}$ & $\begin{array}{r}\frac{24}{14} \\
12 \\
21 \\
15 \\
5\end{array}$ & $\begin{array}{l}11.2 \\
\frac{0}{0.4} \\
1.4 \\
4.7 \\
0.1\end{array}$ \\
\hline $\begin{array}{l}10 \\
11 \\
12 \\
13\end{array}$ & $\begin{array}{l}30 \\
31 \\
30 \\
21\end{array}$ & $\underset{\mathbf{F}+}{\stackrel{M}{\mathbf{M}}}$ & $\begin{array}{l}58 \\
2 \cdot 5 \\
28 \\
53\end{array}$ & $\begin{array}{l}9 \cdot 7 \\
6 \cdot 4 \\
6 \cdot 3 \\
3 \cdot 4\end{array}$ & $\begin{array}{l}7 \cdot 0 \\
0 \\
5 \cdot 2 \\
3 \cdot 4\end{array}$ & $\begin{array}{l}2 \cdot 7 \\
1 \cdot 5 \\
2 \cdot 7 \\
2 \cdot 7\end{array}$ & $\begin{array}{l}2 \cdot 0 \\
3 \cdot 1 \\
2 \cdot 2 \\
3 \cdot 5\end{array}$ & $\begin{array}{l}\text { roup } \\
27 \\
18 \\
40 \\
43\end{array}$ & $\begin{array}{r}22 \\
25 \\
38 \\
144\end{array}$ & $\begin{array}{l}\frac{143}{100} \\
101\end{array}$ & $\begin{array}{r}172 \\
92 \\
92 \\
19\end{array}$ & $\begin{array}{l}278 \\
405 \\
318 \\
384\end{array}$ & $\begin{array}{l}295 \\
218 \\
308 \\
-\end{array}$ & $\frac{\overline{13}}{4}$ & $\frac{\overline{0}}{3 \cdot 5}$ \\
\hline
\end{tabular}

- Lost to the series. † Died. $\mathrm{C}=$ Value at start of treatment. $\mathrm{T}=$ Value at end of treatment, or latest value if still on treatment. $\mathrm{P}=\mathrm{Latest}$ value after stopping 
months there has been no remission of the proteinuria and his plasma albumin has remained low.

Group 3 (Cases 10-13).-In one of these four cases (Case 11) the urine became protein-free during treatment and has remained so for a follow-up period of 13 months. In two cases (Nos. 10 and 12) steroids do not seem to have influenced the course of the disease, and one patient (Case 13) died in uraemia after a steady clinical and metabolic deterioration in her condition over a period of 57 months.

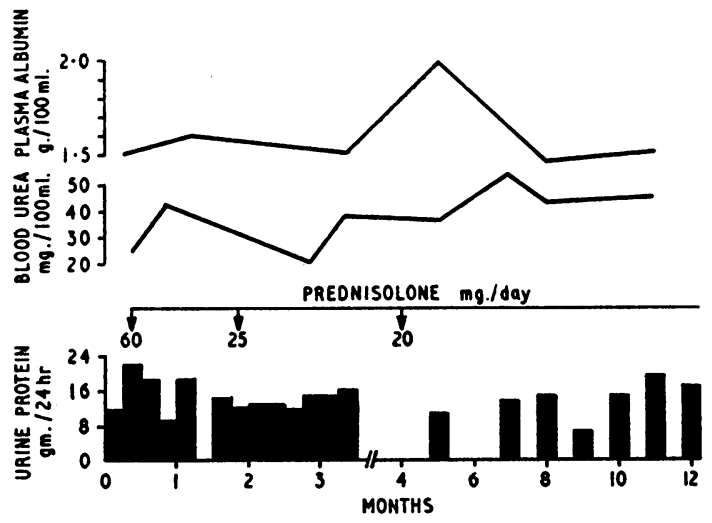

FIG. 3.-Response to prednisolone in Case 3.

The 13 cases for which a histological diagnosis is not available are detailed in Table II. In no case has the urine become free of protein. Cases 19 and 23 have been lost to the series after six and eight months' steroid treatment respectively, owing to non-attendance at the clinic. Cases 25 and 26 have died in renal failure. Eight cases (Nos. 14, 15, 17, 18, 19, 20, 21, and 23) may be said to have improved while on steroid therapy. They show considerable diminution of protein excretion in the urine and elevation of plasma-albumin levels. Apart from proteinuria all have maintained normal renal function, as assessed by the level of blood urea and the clearance of creatinine. Case 17, a 54-year-old woman, was admitted with a five-months history of swelling of legs and ankles, extending to involve the abdomen, hands, and face, and after an attack of frequency of micturition, with red urine, one month previously. Examination on admission showed pitting oedema of the legs, thighs, and sacrum. Her face was puffy. Investigation showed the excretion of protein to be $6.7 \mathrm{~g}$./day. The plasma albumin was $1.5 \mathrm{~g} . / 100 \mathrm{ml}$., the blood urea $41 \mathrm{mg} . / 100$ $\mathrm{ml}$., and the serum cholesterol $655 \mathrm{mg} . / 100 \mathrm{ml}$. Treatment was started with methylprednisolone, $36 \mathrm{mg}$./day, which was reduced to $12 \mathrm{mg}$./day after five months. At the end of 15 months the steroid therapy was withdrawn. The excretion of protein in the urine had fallen to $0.3 \mathrm{~g}$./day and the plasma albumin showed a satisfactory rise to $3.3 \mathrm{~g} . / 100 \mathrm{ml}$. Within four months her proteinuria again became heavy at $11.8 \mathrm{~g} . /$ 24 hours, and the plasma albumin had fallen to $1.6 \mathrm{~g} . / 100 \mathrm{ml}$. Massive oedema of legs, thighs, sacrum, and trunk had returned.
The blood urea had risen to $86 \mathrm{mg} . / 100 \mathrm{ml}$. Treatment was restarted with prednisolone, $80 \mathrm{mg}$./day. Within five weeks the urinary excretion of protein had fallen to $0.9 \mathrm{~g}$./day and over the ensuing 14 months was maintained at a low level, although the urine never became protein-free. The plasma albumin rose to $3.2 \mathrm{~g} . / 100 \mathrm{ml}$. and the blood urea fell to $30 \mathrm{mg} . / 100 \mathrm{ml}$.

Cases 16, 22, and 24 have not improved. In all, the protein excretion continues at a level that has precluded a satisfactory rise in the concentration of serum albumin. In Cases 22 and 24 the blood-urea levels are rising and in Case 22 the clearance of crestinine is falling. Cases 14, 15, 16, 18, 20, and 24 have been taken off steroid therapy, and in all except Cases 16 and 24 the protein excretion has remained at the low levels which were present when steroids were stopped.

\section{Discussion}

Our results show that of 26 cases of the nephrotic syndrome in adults treated with steroids, only two (Cases 4 and 11) responded with complete and so far permanent disappearance of protein from the urine. This represents a success rate of $8 \%$, and is similar to the findings of others using steroid therapy in this condition. A further eight cases have shown considerable improvement (Nos. 1, 6, 9, 14, 15, 18, 20, and 21), with protein excretion diminished to less than $1 \mathrm{~g} . / 24$ hours, satisfactory rise in plasma-albumin concentration, and disappearance of oedema. Eales (1959) treated 41 adults and Johnson and Reader (1959) 26 cases, with disappearance of proteinuria in two and three cases in the two series respectively. Both these reports refer to short courses of steroid using either A.C.T.H. or one of a number of other steroids. Sharpe and Unger (1959) reported the disappearance of proteinuria in two out of six cases, and Blainey et al. (1960) reported complete remission in three out of 21 adults treated with cortisone. Of the 19 cases treated by Burch et al. (1962) seven showed complete remission. Four of the 26 cases studied by Ross and Smith (1963) responded to steroids, in prolonged courses, by complete loss of proteinuria. These 139 cases from the literature, with loss of proteinuria in 21, represent a remission rate of $15 \%$.

Blainey et al. (1960) suggest that the response to steroid in the individual case may be correlated with the histological findings on renal biopsy specimens. Of six of their cases with minimal glomerular changes, three responded with loss of protein from the urine, one was improved, and two were unchanged. No case showing a proliferative or membranous glomerular lesion became protein-free. These findings are not generally supported. Four cases of Burch et al. (1962) were reported as showing minimal lesions and the urine of three of these became protein-free on treatment; while Sharpe and Unger (1959) reported loss of proteinuria in two of six cases with membranous lesions. Ross and Smith (1963) could not correlate response to steroids with the histological findings in their 13 cases. In the present series the one case (No. 1) showing a minimal lesion responded well to treatment, and the

TABLE II

\begin{tabular}{|c|c|c|c|c|c|c|c|c|c|c|c|c|c|c|c|}
\hline $\begin{array}{l}\text { Case } \\
\text { No. }\end{array}$ & Age & Sex & $\begin{array}{c}\text { Duration } \\
\text { oN } \\
\text { Treatment } \\
\text { (Months) }\end{array}$ & \multicolumn{2}{|c|}{$\begin{array}{l}\text { Urine Protein } \\
(\mathbf{g} \cdot / 24 \mathrm{hr} .)\end{array}$} & \multicolumn{2}{|c|}{$\begin{array}{l}\text { Plasma Albumin } \\
(\mathrm{g} . / 100 \mathrm{ml} .)\end{array}$} & \multicolumn{2}{|c|}{$\begin{array}{l}\text { Blood Urea } \\
\text { (mg./100 ml.) }\end{array}$} & \multicolumn{2}{|c|}{$\begin{array}{c}\text { Creatinine Clearance } \\
\text { (ml./min.) }\end{array}$} & \multicolumn{2}{|c|}{$\begin{array}{c}\text { Serum Cholesterol } \\
(\mathrm{mg} . / 100 \mathrm{ml} .)\end{array}$} & $\begin{array}{c}\text { Duration } \\
\text { ofr } \\
\text { Treatment } \\
\text { (Months) }\end{array}$ & \begin{tabular}{|l}
$\begin{array}{l}\text { Urine Protein } \\
\text { (mg./100 ml.) }\end{array}$ \\
$\mathbf{P}$
\end{tabular} \\
\hline $\begin{array}{l}14 \\
15 \\
16 \\
17 \\
18 \\
19 \\
20 \\
21 \\
22 \\
23 \\
24 \\
25 \\
26\end{array}$ & $\begin{array}{l}35 \\
58 \\
28 \\
54 \\
27 \\
45 \\
15 \\
49 \\
24 \\
43 \\
28 \\
24 \\
32\end{array}$ & $\begin{array}{c}\mathbf{F} \\
\mathbf{M} \\
\mathbf{F} \\
\mathbf{F} \neq \\
\mathbf{F} \\
\mathbf{M}^{*} \\
\mathbf{P} \\
\mathbf{F} \\
\mathbf{M} \\
\mathbf{F}^{*} \\
\mathbf{M} \\
\mathbf{F} \\
\mathbf{M} f\end{array}$ & 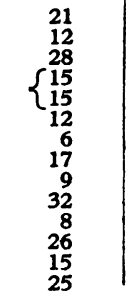 & $\begin{array}{r}9.8 \\
10.9 \\
3.8 \\
61.7 \\
11.8 \\
4.5 \\
17.6 \\
6.2 \\
9.5 \\
21.8 \\
8.6 \\
6.3 \\
8.0 \\
7.0\end{array}$ & $\begin{array}{l}0.9 \\
1.6 \\
2.0 \\
0.3 \\
3.0 \\
1.1 \\
1.9 \\
0.5 \\
0.7 \\
9.1 \\
2.2 \\
3.2 \\
2.8 \\
3.0\end{array}$ & $\begin{array}{l}1.9 \\
2.3 \\
3.7 \\
1.5 \\
1.6 \\
2.5 \\
0.9 \\
1.5 \\
2.2 \\
1.2 \\
1.1 \\
2.3 \\
2.7 \\
2.5\end{array}$ & $\begin{array}{l}3.4 \\
3.0 \\
3.2 \\
3.3 \\
3.2 \\
3.4 \\
3.3 \\
3.9 \\
2 \cdot 0 \\
2.4 \\
2.7 \\
3.6\end{array}$ & $\begin{array}{l}36 \\
47 \\
32 \\
41 \\
86 \\
16 \\
25 \\
78 \\
27 \\
52 \\
29 \\
29 \\
48 \\
34\end{array}$ & $\begin{array}{r}20 \\
36 \\
33 \\
41 \\
30 \\
28 \\
26 \\
33 \\
80 \\
60 \\
64 \\
152\end{array}$ & $\begin{array}{r}165 \\
\frac{16}{63} \\
\frac{9}{92} \\
83 \\
65 \\
60 \\
83 \\
60 \\
83 \\
73 \\
50\end{array}$ & $\begin{array}{r}100 \\
101 \\
55 \\
94 \\
158 \\
102 \\
163 \\
41 \\
49 \\
\frac{79}{23} \\
26\end{array}$ & $\begin{array}{l}380 \\
435 \\
242 \\
655 \\
583 \\
571 \\
750 \\
400 \\
758 \\
588 \\
328 \\
565 \\
404\end{array}$ & $\begin{array}{l}255 \\
266 \\
340 \\
343 \\
295 \\
400 \\
415 \\
124 \\
370 \\
276 \\
382 \\
240\end{array}$ & $\begin{array}{l}47 \\
36 \\
33 \\
\frac{2}{26} \\
\frac{11}{11} \\
= \\
\overline{3} \\
\underline{19}\end{array}$ & $\begin{array}{l}0.4 \\
0.2 \\
1.5 \\
= \\
\overline{0.3} \\
\overline{0.4} \\
= \\
\overline{3.5} \\
4.4\end{array}$ \\
\hline
\end{tabular}

Conventions as for Table I. $\ddagger$ Intermission of 4 months after first 15 months. 
relapse when the steroid dose was lowered after a further remission on a higher steroid dose certainly suggests a relationship between treatment and proteinuria. In the two cases where the urine became protein-free one (Case 4) showed a membranous lesion, and one (Case 11) a mixed proliferative and glomerular lesion.

It is clear that the results so far achieved with steroid therapy in adult nephrosis should be interpreted with caution. The disease is subject to remissions and exacerbations, and procedures to control oedema, such as high-protein, low-salt diets, or diuretics, may in themselves result in lessening of protein excretion in the urine. Rosenheim and Spencer (1956) described three of a group of 13 adult nephrotics in whom the urine became protein-free on simple measures to control oedema, and in a further three cases the protein excretion diminished markedly. The reported results with steroid therapy are no better.

\section{Summary}

Twenty-six cases of the nephrotic syndrome in the adult have been treated with prolonged steroid therapy. All cases were diagnosed, either on percutaneous renal biopsy or on clinical grounds, as being due to glomerulonephritis. The effect of steroid therapy was assessed chiefly by observation of the daily excretion of protein in the urine.
Of the 13 cases in which renal biopsy was performed one showed no definite glomerular lesion. The protein excretion in this case fell to less than $1 \mathrm{~g}$./day. In the remaining 12 cases the glomeruli showed varying degrees of cellular proliferation and capillary wall thickening. The urine of two of these patients became protein-free on treatment and in a further two cases protein excretion fell to less than 1 g. $/ 24$ hours.

In none of the remaining 13 cases did the urine become protein-free, but in five the protein excretion diminished to less than $1 \mathrm{~g} . / 24$ hours.

We wish to thank colleagues who referred patients, and also Mr. Desmond Neill for many of the biochemical determinations.

\section{REFERENCES}

Arneil, G. C. (1961). Lancet, $2,1103$.

Blainey, J. D., Brewer, D. B., Hardwicke, J., and Soothill, J. F. (1960) Quart. F. Med., 29, 235.

Burch, R. R., Pearl, M. A., and Sternberg, W. H. (1962). Ann. intern. Med., 56, 54.

Charlton, D., Latner, A. L., Platt, J. W., Smart, G. A., Thompson, R. B., and Walker, W. (1958). Acta med. scand., 16i, 33.

Eales, L. (1959). S. Afr. F. Lab. clin. Med., 5, 125.

Johnson, J. R., and Reader, R. (1959). Aust. Ann. Med., 8, 200.

Lange, K., Strang, R., Slobody, L. B., and Wenk, E. J. (1957). Arch intern. Med., 99, 760.

Peters, J. H. (1942), 7. biol. Chem., 146, 179.

Rosenheim, M. L., and Spencer, A.'G. (1956). Lancet, 2, 313.

Ross, E. J., and Smith, J. F. (1963). Quart. F. Med., 32, 65.

Sharpe, A. R., and Unger, A. M. (1959). Arch. intern. Med., 104, 684

\title{
Rapid Quantitative Barbiturate Estimation
}

\author{
A. S. CURRY,* M.A., PH.D., F.R.I.C.
}

Brit. med.F., 1964, 1, 354-355

A recent report (Curry, 1963a) gave a method of screening 2-ml. blood samples for barbiturate. This involved the use of magnetic stirring with chloroform, removal by suction of the aqueous layer, and, after washing, reaction to form chloroform-soluble mercury barbiturate. After removal of excess mercury a positive reaction shows itself as an orange colour on addition of dithizone solution.

It has been found possible to adapt the method to give a quantitative assay. This greatly increases its value, because estimation of the severity of the poisoning can now be made without recourse even to a colorimeter. The time for the analysis remains at five to eight minutes.

The modification consists in titrating the mercury barbiturate in the chloroform layer with a standard dithizone solution. By stirring with $0.5 \mathrm{~N}$ ammonia between successive additions the end-point is seen as a darkening of the chloroform layer and the appearance of a yellow colour in the ammonia.

\section{Method}

The apparatus is essentially similar to that described before (Curry, 1963a), but it has been found more convenient to decrease the size of the beaker to $50 \mathrm{ml}$. The optical density of the dithizone solution in chloroform at $605 \mathrm{~m} \mu$ has been increased to 3 ( $15 \mathrm{mg}$. in $400 \mathrm{ml}$.).

One millilitre of blood and $2.5 \mathrm{ml}$. of phosphate buffer $(\mathrm{M} / 15$ at $\mathrm{pH} 6.95)$ are magnetically stirred with $15 \mathrm{ml}$. of chloroform for three minutes. The aqueous layer is removed by suction and by washing with two $15-\mathrm{ml}$. aliquots of water in the usual way. It is important at this stage not to remove any of the chloroform layer ; if a trace is inadvertently lost it is made up by dropwise addition until the level again reaches the lower end of the suction-tube. The chloroform layer is then stirred for two minutes with $1 \mathrm{ml}$. of mercury bicarbonate solution containing $200 \mu \mathrm{g}$. of mercury ion per ml. After settling, $15 \mathrm{ml}$. of water is added and then immediately removed by the suction-tube. It is essential to remove as much as possible of the aqueous layer. If as little as $0.2 \mathrm{ml}$. remains this will give a subsequent positive blank value equivalent to 0.3 mg. of barbiturate per $100 \mathrm{ml}$. of blood; $3 \mathrm{ml}$. of $0.5 \mathrm{~N}$ ammonia solution is pipetted on top of the chloroform layer followed by successive $1-\mathrm{ml}$. aliquots of dithizone in chloroform solution. After each addition of dithizone the solution is stirred and the layers are allowed to separate. The end of the titration is seen as the appearance of a green darkening to the previously orange chloroform layer; the ammonia layer also takes up the unchanged dithizone and goes yellow.

Each millilitre of dithizone solution corresponds to $1 \mathrm{mg}$. of barbiturate per $100 \mathrm{ml}$. of blood.

At low barbiturate concentrations $(2 \mathrm{mg} . / 100 \mathrm{ml}$. or less) the blank value is of great importance. If, before adding dithizone, the excess mercury reagent is removed by washing with an additional $15 \mathrm{ml}$. of water the blank is reduced to zero. Such washing, however, results in loss of mercury barbiturate from the chloroform layer, and recovery of amylobarbitone, pento-

* Home Office Forensic Science Laboratory, Harrogate. 